\title{
КОЛОНКА ГЛАВНОГО РЕДАКТОРА
}

\section{П. С. Гуревич \\ DOI: 10.7256/1999-2793.2013.12.10162}

\section{ЗЛО ПРОТИВ ДОБРА}

\begin{abstract}
Аннотация. Можно ли помыслить такую циивилизацию, в которой зло не только имеет огромную притягательную силу, но получает даже идеологическое и метафизическое обоснование? Обсуждая вопрос о соотношении добра и зла, философы, как правило, рассматривают добро как благо, а зло как неизбежное присутствие порока. Они размышляют о том, откуда зло проникло в этот мир, можно или следует его устранять. Они склоняются к мысли, что зло, судя по всему, имеет особую миссию, но какую?- и здесь теологи и философы буквально изнемогают в спорах и порой парадоксальных точках зрения. Идея поразительной сплетённости добра и зла была предметом острых дискуссий во все времена. Сама проблема хранит в себе глубочайшее метафизическое напряжение. Опыт последних столетий показал, что добро вовсе не теснит зло, а скорее, наоборот, у зла обнаруживаются столь безупречные доводы, что оно в современных исследованиях обретает несомненную онтологическую опору. Автор статьи пытается понять, в чем смысл теологического истолкования зла, почему «добро» и «зло» коррелятивны, отчего наличие зла рождает мысли о том, что Бог не всеблаг, не силен и т.д. Возникает вопрос, который был поставлен еще С. Къёркегором: не является ли существование зла своеобразным парадоксом?
\end{abstract}

Ключевые слова: философия, добро, зло, Бог, выбор, свобода, теодиея, мораль, воля, теология.

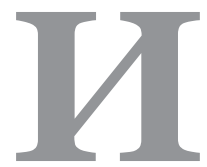

звестно, что Д. Юм полагал невозможным обоснование объективных стандартов добра и зла. Он считал зло неизбежным в природе, где не властвует человеческий разум. Там оно оказывается продуктом вселенского хаоса. Возможно, закономерности природы целесообразны. Но они не соотносятся с категорией добра. Эти представления можно сегодня проиллюстрировать строчками Николая Заболоцкого:

\section{Жук ел траву, жука склевала птица, Хорёк пил мозг из птичьей головы. И страхом перекошенные лица Живых существ глядели из травы.}

Однако в обществе царит человеческий разум. Здесь выбор добра и зла может быть вполне осмысленным решением.

В романе Роберта Шекли «Цивилизация статуса» описаны события, которые привели главного персонажа этого произведения к ссылке не некую планету, где обитают преступники и где зло является своеобразной религией. Священник из этого мира произносит проповедь, в которой он убеждает землянина в том, что зло существует внутри нас, что оно вдохновляет человека на дела, требующие силы и выносливости. Именно поэтому на этой планете существует культ зла. Какое же существо считают здесь идеальной личностью? Такое создание, которое готово пронырливо использовать любую возможность для собственной карьеры. Такой человек готов принять смерть с достоинством и вместе с тем убивает других людей без жалости. Это чувство считается унизительным. И вот аргумент, сходный с мыслью Юма: зло есть отражение безразличной и бесчувственной Вселенной. Оно поэтому неизменно, может обнаруживать себя в самых неожиданных сферах человеческой жизни. Священник толкует о том, что жители этой планеты поклоняются Злу как воплощению Великого Черного. Именно в этом боге они находят семь смертных грехов, сорок преступлений и сто один порок.

Великий Черный - что-то вроде божества. А люди стремятся быть его образом и подобием. Бог способен явиться людям в ужасной красоте своей огненной плоти. Жители планеты поклоняются Государству как высшему проявлению способности человека ко Злу. Землянина преследуют, потому что он уклоняется от посещений Черной Мессы. На планете Омега даже праздники имеют очевидные предлоги для массовых убийств. Роман заканчивается возвращением 


\section{Философия и культура 12(72) • 2013}

героя на Землю, где за это время произошли странные перемены. Жизнь на родной планете стала слабой, пассивной, никчёмной. Вывод: без торжества Зла цивилизация гибнет.

Но какова природа зла в человеческом обществе? Юм полагал, что в социальных событиях, как и в природе, все сплетено, перемешано. Подобно тому, как солнце порождает цветущий мир, бури и грозы приносят разрушение этой благодати. Солнце уничтожает то, что питается влагой рос и дождей. Война, разумеется, истребительна. Но зато массовая гибель людей спасает оставшихся от голода. Некое царство утопает в изобилии. Добро торжествует. Но неожиданно приходит чума. И царство гибнет. Воцаряется зло. Полководец одержал победу над врагом. Народ торжествует. А что делать народу, который впал в порабощение? Роптать на козни судьбы. Охотник считает за благо застрелить зайца. Но у зайца, надо полагать, по этому поводу другое мнение. Добро и зло, добродетель и порок, счастье и несчастье, везенье и невезенье, мудрость и глупость, мораль и безнравственность, в жизни не существуют в чистом виде. Они переплетены, смешаны. Последовательно проведенная логика может обернуться абсурдом. Буйная радость повергает человека в состояние печали. Сладкая порочность способна испортить радость жизни. Воплощенная надежда оборачивается разочарованием.

«Мир, в котором мы обитаем, представляет собой как бы огромный театр, писал Д. Юм, причем подлинные пружины и причины всего происходящего в нем от нас совершенно скрыты, и у нас нет ни знания достаточного, чтобы предвидеть те бедствия, которые беспрестанно угрожают нам, ни силы достаточной, чтобы предупредить их. Мы непрестанно балансируем между жизнью и смертью, здоровьем и болезнью, изобилием и нуждою, все это распределяется между людьми тайными, неведомыми причинами, действие которых часто бывает неожиданным и всегда необъяснимым. И вот эти-то неведомые причины становятся неизменным предметом наших надежд и страхов; и если наши аффекты находятся в постоянном возбуждении благодаря тревожному ожиданию грядущих событий, то и воображение наше также действует, создавая представления об указанных силах, от которых мы находимся в столь полной зависимости ${ }^{1}$.

${ }^{1}$ Юм Д. Естественная история религии // Юм Д. Соч. в 2-х т. М., 1965. Т. 2. С. 371.

1656
Существование зла всегда было популярным аргументом в нападках философии на религию. Философы его рассматривали как доказательство бессилия Бога предотвратить его или как свидетельство несовершенства божества. Теология отвечали на это так. Бог всесилен и в состоянии сделать так, чтобы не было зла. Зло существует для благой цели. Если воспринимать проблему должным образом, то зло является даже благом.

Основной аргумент в пользу существования зла, с точки зрения теодицеи, состоит в утверждении, что человек должен имеет возможность выбора между добром и злом. Если он не может выбрать зло, он не может вообще понять, что ему выбирать. Поэтому существование зла совместимо с существованием и благостью Бога. Теисты признают, что грехопадение привело человека к возможности выбрать что-то конкретное, а не просто сделать выбор. Таким образом, защита свободы выбора переходит защиту зла как такового.

Однако предлагаемую текстами защиту Бога нельзя признать удачной в силу следующих причин. Во-первых, в мире существует «естественное» зло, которое невозможно никак оправдать. Например, гибель детей в результате взрыва ядерного реактора или мощного наводнения. Во-вторых, теодицея утверждает, что из зла вытекают благие последствия. При таком подходе смерть ребенка можно рассматривать как желание Бога привлечь внимание к проблемам здравоохранения, помощи слаборазвитым странам и т.д. Подобное утверждение приводит к антропоморфизации Бога, к трактовке отношений между ним и людьми в виде отношений родителя и детей, учителя и учеников. Зло в данном аспекте рассматривается как средство достижения благородных целей.

Утверждение, что Бог производит добро посредством естественного зла, противоречит моральной задаче, которую религия ставит перед человеком. С точки зрения морального закона, говоря словами Канта, мы должны каждого человека рассматривать как цель, а не как средство. С точки зрения теодицеи, мы должны согласиться с тем, что Бог использует людей как средство для достижения добра. Теодицея вступает, таким образом, в конфликт с религиозной моралью.

Далее теодицея ставит под сомнение утверждение, что человек знает разницу между добром и злом. Получается, что отдельный 


\section{Колонка главного редактора}

человек не в состоянии отличить сегодняшнее зло от будущего добра, из него проистекающего. Следовательно, он должен руководствоваться не собственным моральным чувством, а уповать на премудрость божию. Поэтому логично не помогать страдающим, а позволить совершиться злу, поскольку оно может быть средство утверждения будущего добра. Утверждение теодицеи, что зло производит благо и совместимо с существованием Бога, вступает, таким образом, в противоречие с центральным религиозным положением, что человек в состоянии отличить добро от зла. «Добро не располагается более по ту сторону зла» ${ }^{1}$.

Философы утверждают, что наличие зла в мире означает отрицание Бога. Парадокс заключается в том, что это утверждение, так же как и точка зрения теодицеи, приводит к отрицательным последствиям для морали. Д. Юм, например, считает, что в природе зло естественно и неизбежно как часть слепой игры стихийных сил. С этой точки зрения, говорить о морали применительно к природе и человеку бессмысленно. Человек из морального агента превращается в морального наблюдателя. Морально безразличный универсум не знает различия между добром и злом, в нем существуют только события.

Религия впадает в противоречия, пытаясь решить проблему зла, и показывает, что цена решения этих противоречий - утрата морального агента. Отсюда следует, что проблема зла извечна и неразрешима и является серьезной проблемой в понимании морального агента им в религиозном и в нерелигиозном контексте. Возможно, проблема зла не является ни проблемой, ни антиномией, но тем, что Кьёркегор назвал бы парадоксом, из которого разум не в состоянии выбраться. В этом смысле проблема зла не является свидетельством крушения религии в результате внутренних противоречий, а характеризует глубину понимания ею человека как морального существа ${ }^{2}$.

Некоторые исследователи доказывают совместимость существования Бога с наличием зла. Они убеждены, что зло имеет позитивную ценность. Позитивная или негативная ценность вещи является общей ценностью, состоящей из инструментальной и внутренней ценности. Если вещь имеет позитивную ценность, то ее

\footnotetext{
${ }^{1}$ Бодрийяр Ж. Прозрачность зла. М., 2006. С. 121.

${ }^{2}$ Гуревич П. С. Этика: Учебник для бакалавров. М., 2013.
}

существование большее благо, чем несуществование. Если же она имеет негативную ценность, то лучше, чтобы она не существовала. Можно говорить о степени позитивной и негативной ценности. Аргумент от зла по сути дела можно считать выражением гедонистического подхода к ценностям. Утверждение, что Бог не создал мир, в котором существует лучший из возможных балансов между позитивными и негативными ценностями, исходит из того, что в мире существует слишком много негативных ценностей. Позитивные и негативные ценности в данном случае определяются через связь с удовольствием и болью.

Традиционно необходимость наличия морального зла обосновывается аргументом свободной воли. Поскольку свободная воля является необходимым условием морального добра, то возможность морального зла имеет позитивную ценность. Вторичный эффект возможности морального зла состоит в реальном существовании морального зла: поскольку возможно, что кто-то выберет неправильный поступок, двойной эффект этой возможности состоит в том, что ктото фактически будет действовать неправильно. Так реальное моральное зло является двойным эффектом возможности морального зла, то есть свободной воли. Возражение, что количество зла слишком велико и часть его не является необходимой, приводит к отрицанию существования Бога. В контексте проблемы зла мы не можем сказать, какое количество зла не оказывается необходимым.

Нельзя ли сказать, что зло является внутренне плохим, но инструментально хорошим? Доктрина двойного эффекта позволяет нам утверждать, что, поскольку возможно существование зла как необходимости для существования свободной воли и морального блага, то позитивная ценность зла превышает его позитивную ценность, несмотря на то, что зло сохраняет все свои плохие качества.

Позитивное значение естественного зла доказывается следующим образом. Существование мира является более предпочтительным, чем его несуществование. Исходя из того, что мир естественное добро, необходимо признать, что события, необходимые для его существования, также имеют позитивную ценность. Естественное добро оправдывает естественное зло, поскольку без второго невозможно существование первого. 


\section{Философия и культура 12(72) • 2013}

Если исходить из того, что существование этого мира лучше, чем его несуществование, то необходимо согласиться, что зло имеет позитивную ценность: моральное как двойной эффект морального добра, а естественное как двойной эффект естественного добра. В каждом из этих случаев существование универсума, даже если он не является лучшим из всех возможных миров, является позитивной ценностью, которая «оправдывает» то зло, которое существует.

С теологической точки зрения, существование зла в мире совместимо с существованием благого и всесильного Бога, поскольку мир со злом лучше, чем мир без зла. Аргумент о свободе воли как основе морального индивида исходит из нераздельности добра и зла. Мир без зла и свободы воли, возможность нравственного выбора несовместимы. Поэтому, с теологической точки зрения, проблемы зла просто не существует.

Скептический подход заключается в подчеркивании того, что существует добро, которое не связано со злом и наоборот. Бог как всесильное существо в состоянии предотвратить существование любого зла. Если этого не произошло, значит Бога нет. Существование зла в мире в огромном количестве является свидетельством против существования Бога. Следовательно, в рамках данного подхода проблема зла также отсутствует.

Ни теологи, ни скептики не смогли пока правильно поставить философскую проблему зла. Вопрос состоит не в том, совместимо ли существование зла с существованием Бога, а в том, действительно ли любое зло может быть реально предотвращено. Этот вопрос приводит к рассмотрению таких вещей, как модальности, ценности и метафизические онтологии. Подход в рамках совместимости-несовместимости, возможности предотвратить - невозможности предотвратить оказывается слишком примитивным. Поэтому необходимо проблему зла выделить из теологической проблематики и рассматривать как самостоятельную философскую проблему.

Проблема добра и добра, как это очевидно, соотносится с темой свободы. Один взгляд на свободу таков: все, что случается, имеет такие причины, что может возникнуть только конкретный эффект и ничего больше. Для другого события должна быть другая конкретная причина. Однако это не отрицает реального существования свободы. Человек свободен тогда, когда он не принуждается внешними силами и самостоятельно выбирает образ своих дей- ствий. Свобода существует в том случае, если человек может сделать то, что он хочет. Свобода совместима с детерминизмом.

Согласно второму, либеральному взгляду, человек свободен тогда, когда причинные условия недостаточно сильны, чтобы заставить его действовать определенным образом. Когда эти условия достаточно сильны для детерминации поведения человека, он теряет способность выбрать между альтернативными способами действия. Без возможности осмысленного выбора человек не свободен. В любом случае свобода совместима с каузальным детерминизмом.

Вопрос о сущности свободы лежит в центре всех споров о существовании зла и совместимости его с Богом. Критики теологии обычно утверждают, что свобода совместима с причинностью. Существует одна теологическая традиция, разделяющая этот взгляд - кальвинистская или реформистская.

Теологические представления о совместимости свободы человека и ее детерминированности не могут быть успешно опровергнуты антитеологическим утверждением, что если свобода совместима с детерминизмом, то Бог был обязан сделать людей такими, чтобы они всегда выбирали добро. Кальвинистская теология не в состоянии доказать, что переход от того, что Бог мог сделать, к тому, что он обязан сделать, является в данном случае неправомерным. Существование зла делает концепцию совместимости свободы и детерминизма беззащитной и неспособной отстоять представления о Боге как всемогущем, всевидящем и всеблагом существе. Только концепция свободы воли позволяет совместить существование зла с существованием христианского Бога.

У библейских авторов не возникало сомнений в существовании Бога. Поскольку оно было очевидным для всех, то сама вера в него не считалась религиозной или этической добродетелью. Христианские теологи в эллинистическом мире впервые столкнулись с тем, что интеллигентные и честные люди были агностиками или атеистами. Поэтому возникла проблема скрытости Бога: почему он не являет себя очевидным для всех образом? Вера в Бога стала религиозной добродетелью. Скрытость бога стала частью проблемы зла. Так отсутствие очевидности существования Бога становится проблемой теодицеи.

Бог создал мир таким, чтобы он казался возникшим и существующим без его участия 


\section{Колонка главного редактора}

и присутствия. Бог создал человека свободным, чтобы он мог сделать выбор между верой и неверием, между добром и злом. Находящийся в мире, полном борьбы и страданий, человек из греховного состояния должен свободно и без принуждения возлюбить Бога и поверить в него. Поэтому не существует рациональных доказательств бытия Бога, так как они были бы совместимы со свободой выбора.

Выбор может быть свободным только в том случае, если человек точно знает, что он выбирает. Если нет очевидных доказательств существования Бога, то тогда возможен выбор между знанием и слепой верой. Здесь нет ни свободы, ни выбора. Фатальная проблема состоит не в восприятии двусмысленности мира и не в эпистемо- логии «веры» как уверенности, а в классическом теизме, заставляющем его утверждать, что Бог скрыт от нас. Бог не создавал этот мир с целью проверки нашей готовности верить в него вопреки или благодаря очевидности. Процессуальные теологи утверждают, что у них есть рациональные основания для их теистических верований, которые заслуживают беспристрастного рассмотрения. В качестве теодицеи понятие «эпистемологической дистанции» как гаранта свободы является моралью, религиозно и философски неприемлемой. Но если принять процессуальное представление о Боге и связи Бога с миром, то двусмысленность мира теряет свой характер божественного обмана и становится выражением борьбы Бога за самораскрытие.

\section{Список литературы:}

1. Бодрийяр Ж. Прозрачность зла. М., 2006.

2. Гуревич П. С. Этика: Учебник. М., 2013.

3. Гусейнов А. А. Философия и этика. Сборник научных трудов к 70-летию академика А. А. Гусейнова. М., 2009.

4. Соловьев Э. Ю. История толкует нас. Очерки по истории философии и культуры. М., 1991.

5. Шекли Р. Цивилизация статуса: Повести. Рассказы. М., 2000.

\section{References (transliteration):}

1. Bodriiyar Zh. Prozrachnost» zla. M., 2006.

2. Gurevich P.S. Etika: Uchebnik. M., 2013.

3. Guseinov A.A. Filosofiya i etika. Sbornik nauchnykh trudov k 70-letiyu akademika A. A. Guseinova. M., 2009.

4. Solov'ev E. Yu. Istoriya tolkuet nas. Ocherki po istorii filosofii i kul'tury. M., 1991.

5. Shekli R. Tsivilizatsiya statusa: Povesti. Rasskazy. M., 2000. 